Nama : Muh. Akbar

Nim : $\quad$ : $\quad 90100118026$

Mata Kuliah : Sejarah Pemikiran Ekonomi Islam

\title{
Konsep Ekonomi Al-Ghazali dan Ibnu Khaldun
}

Salah satu tokoh pemikir ekonomi Islam yang memiliki peran besar dalam mengembangkan ekonomi Islam adalah Al-Ghazali. Beliau hidup dizaman keemasan Islam sekaligus sebagai salah satu pelopor di dalamnya. Al-Ghazali yang merupakan penulis produktif pada masanya. Dengan kemahiran beliau dalam ilmu pengetahuan, ditengarai Al-Ghazali menjadi tokoh yang membawa pengaruh terhadap para pemikir Barat pada Abad pertengahan. ${ }^{1}$ Bahkan, di Baghdad Al-Ghazali banyak diberikan pangkat, kehormatan, harta dan kedudukan yang sudah barang tentu diraih lewat keilmuwannya. $^{2}$

Pembahasan Al-Ghazali yang memberikan banyak pengaruh yaitu mengenai konsep uang dalam ekonomi Islam. ${ }^{3}$ Penjelasannya mengenai konsep uang tertuang dalam salah satu karya monumentalnya yaitu kitab ihya ulum al-Din. Di dalamnya AlGhazali banyak membahasa di antaranya terkait dengan evolusi uang dan berbagai fungsinya. Lewat pembahasannya, Al-Ghazali menjelaskan bagaimana uang dapat menjadi solusi terhadap berbagai problematika yang timbul lewat aktivitas barter. Lebih lanjut Al-Ghazali menyatakan bahwa uang tidak memiliki nilai guna langsung pada dirinya. Akan tetapi hanya berfungsi untuk dijadikan alat tukar untuk bermacam-macam barang lainnya.

Selain itu, terdapat pula satu tokoh pemikir Islam yang cukup membawa pengaruh terhadap banyak pemikir lainnya di antaranya juga pemikir Barat. Dia adalah seorang cendekia muslim yang dikenal dengan nama Ibnu Khaldun. Dengan berbagai macam hasil karya beliau, yang menjadi karya terbesarnya adalah Al-Ibar (Sejarah

\footnotetext{
${ }^{1}$ Adiwarman Azwar Karim, Sejarah Pemikiran Ekonomi Islam (Depok: Rajawali Pers, 2004).

${ }^{2}$ Prof. Dr. H. Boedi Abdullah, Peradaban Pemikiran Ekonomi Islam (Bandung: CV Pustaka Setia, 2010).

${ }^{3}$ Soritua Ahmad Harahap, "Pemikiran Imam Al-Ghazali Tentang Fungsi Uang," Laa Maisyir: Jurnal Ekonomi Islam 6, no. 1 (2019).
} 
Dunia). ${ }^{4}$ Dalam karya-karya Ibn Khaldun ini tidak luput penjelasan beliau tentang teori perekonomian di antaranya mengenai konsep uang dalam Islam.

Lewat kutipannya, beliau menyatakan bahwa dua uang logam yang dalam hal ini emas dan perak adalah sebagai ukuran nilai. Karenanya dengan menjadikan emas dan perak sebagai standar moneter didukung juga oleh Ibnu Khaldun. Baginya pembuatan uang logam tersebut menjadikan sebuah jaminan yang dilakukan oleh penguasa dengan sekeping uang logam mengandung sejumlah kandungan emas dan perak tertentu.

\section{DAFTAR PUSTAKA}

Abdullah, Prof. Dr. H. Boedi. Peradaban Pemikiran Ekonomi Islam. Bandung: CV Pustaka Setia, 2010.

Harahap, Soritua Ahmad. "Pemikiran Imam Al-Ghazali Tentang Fungsi Uang." Laa Maisyir: Jurnal Ekonomi Islam 6, no. 1 (2019).

Karim, Adiwarman Azwar. Sejarah Pemikiran Ekonomi Islam. Depok: Rajawali Pers, 2004.

${ }^{4}$ Karim, Sejarah Pemikiran Ekonomi Islam. 